\title{
The Influence of Frame Dependence on Investment Decisions made by Listed Property Fund Managers in South Africa
}

\author{
${ }^{*}$ Gert Abraham Lowies, John Henry Hall, Christiaan Ernst Cloete \\ University of Pretoria, South Africa \\ *braam.lowies@up.ac.za
}

\begin{abstract}
Behavioural finance describes investors' and managers'behaviour in terms of their interactions, andhow their behaviour subsequently influences financial and capital markets. One aspect of behavioural finance, frame dependence, reflects the fact that decision-makers may model decisions about problems using subjective frames. Such decisions may lead to errors in judgement. This study's objective was to determine whether frame dependence influences listed property fund managers in South Africa's property investment decisions.Therefore, the study examinedquestionsrelating to the disposition effect and loss aversion,as well asfactors influencing selling decisions and the time and difficulty involved in making buying and selling decisions. The study surveyed the fund managers of all South African-based property funds listed on the Johannesburg Securities Exchange (JSE). Non-parametric statistical measures were used.The resultsreveal the presence of the disposition effect and a strong desire to cut losses as a motivating factor to sell a property. In the context of the difficulties associated with, and time spent in, buying new properties, it appears that South African property fund managers are, to some extent, lossaverse. This study recommends that fund managers be alerted to the presence of frame dependence in their decisions, so that they canincorporate it in their normative investment strategies. They need to know that they are loss averse in their investment decision-making, resulting ina possible loss of perfectly positioned, profitable investment opportunities. This study expands the body of knowledge surrounding property investment decision behaviour in an emerging market.
\end{abstract}

Keywords: Behavioural finance, frame dependence, disposition effect, loss aversion, property fund managers

\section{Introduction}

The process by which human beings make decisions has been a topic of interest for the past century. In this regard, Ye \& Dent (2009) argues that understanding people's behaviour in a decision-making context can enhance the decision-making process. Research on decision-making is often based on assumptions relating to human rationality, including consistency and coherence (Tversky \& Kahneman, 1981). In traditional financial theory, decision-making models are based on the assumption thatrational agents make rational decisions. Rationality presupposes that, when agents receive new information, they revise their viewsand make normatively satisfactory investment decisions based on these revised views (Barberis \& Thaler, 2003). The normative decision-making paradigmused in traditional financial theory led to the development of models such as Von Neumann and Morgenstern's (1947) expected utility theory, which was followed by models such as the Efficient Market Hypothesis (EMH) (Fama, 1970). According to Shiller (2003), the "efficient markets theory reached its height of dominance in academic circles around the 1970s. At that time, the rational expectations revolution in economic theory was in its first blush of enthusiasm, a fresh new idea that occupied the centre of attention". Contrary to the normative decision-making framework, the fieldof behavioural finance rejects the notion that agents tend to maximise utility through decision-making. Behavioural finance argues that the axioms of expected utility are, in fact, violated as a result of the presence of behavioural aspects (Stracca, 2004). Godoi, Marcon\& Da Silva (2005) suggest that investors are subject to biases and framing dependence that can lead to errors in judgement in investment decision-making. In line with this argument, a study by Menkhoff and Nikiforow (2009) found that, because of their behavioural biases, German fund managers who endorse behavioural finance view markets differently from those fund managers who do not endorse behavioural finance. Doeswijk (1997) reported similar findings among Dutch fund managers.

A growing body of research is exploring the relatively new research field of behaviour and property investment. French \& French (1997), Gallimore, Hansz \& Gray (2000) and Black, Brown, Diaz III, Gibler \& Grissom(2003) all emphasise the influence of behavioural aspects in property investment decision- 
making. Studies by Crosby \& McAllister (2004) and MacCowan \& Orr (2008) have investigated the behaviour of property fund managers with regard to individual and mixed-asset funds. This study focused on an investigation of the influence of frame dependence as a behavioural aspect in the South African listed property fund market.The construct of frame dependence reflects the fact that problems in respect of decision-making may be modelled in different frames from those of the decision-maker (Barberis \& Thaler, 2003). When a decision-maker's despondency aboutpotential losses is strongerthan the person's hope of gains in making investment decisions, this results in the disposition effect. The result is that adecision-maker behaves in a loss averse manner by holding on to loosing investments too long and selling winning investments too soon and then misses profitable investment opportunities. Frame dependence gives way to the disposition effect, one of the key building blocks of the prospect theory discussed in the literature review. The disposition effect implies that people's despondency towards financial losses is higher than their despondency towards financial gains. An authoritative study by Tversky \& Kahneman (1981) shows the effect of frame dependence in an investment realm, and studies by Rabin (1998), Shefrin (2002), Godoi et al. (2005), Chen et al. (2007) and Szyszka (2010) illustrate the disposition effect, loss aversion and feelings of regret in respect of investors' selling "winners" and holding on to "losers" as investments.

Previous research was conducted only on developed economies. Thus far, in the emerging market context in general and the South African context in particular,only limited research has been undertaken on human behaviour in the form of frame dependence, and how it influences property investment decisionmaking. This study fills the gap that existed in an emerging market context by investigating and showing the influence of frame dependence on investment decisions made by decision-makers in an emerging market background, such as South Africa. The South African listed property fund industry has developed into one of the country's main investment industries over the last 12 years. According to the South African Property Owners Association (SAPOA) and the Investment Property Databank (IPD) South Africa Annual Property Index, 2011, market capitalisation increased from R7 billion in 2000 to R205 billion by the end of 2011. However, the total return of the sector decreased significantly from a high of $35 \%$ in 2006 to a return of $10.4 \%$ at the end of 2011 . This slump can be attributed mainly to the 2008 financial crisis. Nevertheless, listed property still outperformed equities $(2.6 \%)$ and bonds $(10.1 \%)$ as an investment class in South Africa by December 2011. Mooya (2010) argues that although South Africa has a first world financial system that creates a positive environment for property developers and investors, the lack of economic growth, increasing levels of unemployment and high level of unequal income distribution typical of a third world economy also persist in the country.

A priorstudy by Ramabodu, Kotze \& Verster (2007) concluded that the South African property industry is unique because South Africa is a country of diversity and cultural differences that need to be acknowledged. Their findings illustrate the environment in which property investors in South Africa make investment decisions. The benefit of the current study is that property fund managers can gain a better understanding of how they perceive their decisions, given the unique environment where they make their decisions. The main objective of this study was to ascertain whether frame dependence, particularlythe disposition effect and loss aversion, influence the investment decisions made by listed property fund managers in South Africa. The fund managers selected for this study were individuals (not organisations) with whom the power vests to make a final investment decision. In order to test for the influence of frame dependence on investment decisions, this study soughtto answer the following questions:

- Do property fund managers display a tendency to hold on to losing properties too long and to sell winning properties too soon?

- What are the most important factors that influence the selling decisions of property fund managers?

- Is the decision to buy more difficult to make thanthe decision to sell property, or vice versa?

- Is the decision to buy more time consuming thanthe decision sell property, or vice versa?

The research questions posed above addressed the main objective of this study, because the questions were specifically designed to focus on the disposition effect and loss aversion as components of frame dependence. This study is a pioneering attempt to establish whether frame dependence in the form of the disposition effect and loss aversion influences the investment decision-making of property fund managers in an emerging economy such as South Africa. The study expanded on similar work published by Henneberry \& Roberts (2008) and MacCowan \& Orr (2008), whose studies focused on the United Kingdom (UK), and by Fogel \& Berry (2006), whose study was based on the United States (US). To achieve the aim of this study, a comprehensive literature review was conducted to supply the theoretical basis for 
the empirical survey-based testing. The theory focuses ontraditional (or normative) financial theory ranging from neoclassical economicsto the expected utility theory, versus the field of behavioural finance, prospect theory as a descriptive model, and behavioural aspect frame dependence with reference to the disposition effect and loss aversion. This review is followed by an explanation of the research method, the analysis of the results and a conclusion and recommendations.

\section{Literature Review}

In this section of the study, the traditional (or normative) financial theory ranging from neoclassical economics to the expected utility theory versus the field of behavioural finance is discussed. Prospect theory as a descriptive model is explained. Next, literature that relates to the behavioural aspect of frame dependence is discussed, with specific reference to the disposition effect and loss aversion.

The normative approach to investment decision-making: The theory of value and asset distribution among social classes forms the basis for the neoclassical economic theories. According to John Maynard Keynes (1936), value was defined as a function of supply and demand, and this came to be known as "the concept of marginalism". Hennings \& Samuels (1990) explain that the concept of marginalism acquired various meaningsas it evolved, including the marginal utility theory of value, adjusting at the margin, and forced maximisation by economic role players that led to the theory of price and asset allocation. All the neoclassical theories are based on the construct of the rational person, who is claimed to make rational decisions, although, as Markowitz (1959) jokingly admits, "[t]he Rational Man, like the unicorn, does not exist". Sargent (2010) indicates that the proponents of the theory of rational expectations suggest that people base their decisions on maximum utility as their main goal. Schoemaker (1980) points out that, for a long time, economic debate has revolved around the actual measurement of utility and its absoluteness. Due to this debate, Von Neumann and Morgenstern (1947) developed the expected utility theory in an effort to capture the concept of rational decision-making under risk.Traditional normative theory supports the notion of the core of rational decision-making under risk, assuming that nobody would wittingly wish to violate axioms such as complete ordering, continuity, independence, unequal probability and complexity. Savage (1954) expanded normative research by incorporating the concept of "subjective probability" into the expected utility theory. The normative models have been criticised by a number of scholars. For example, Tversky (1975) notes the domination of the expected utility theory of the analysis of decision-making under uncertain conditions, remarking that this theory is applicable to both normative and descriptive theoretical frameworks. He argues that the axioms of the expected utility theory are recognised as being in line with the principles of rational behaviour of decision-making under uncertainty, but that the expected utility theory is implausible in terms of its axioms, as these axioms are of a descriptive nature (Muneer \& Rehman, 2012). Research conducted by Frederick, Loewenstein \& O'Donoghue (2002) found only limited evidence in support of the discount utility model. Frederick et al. (2002) point out that even when positing the theory, Samuelson (1937) raised concerns about the model's descriptive pragmatism.

The behavioural approach to investment decision-making: Normative theories such as the expected utility theory state that sensible (reasonable) people act in a certain way. However, the principles of descriptive or positive theories of choice, such as the prospect theory, rely on observations of what people actually do. Kahneman \& Tversky (1979) developed a descriptive model of choice - prospect theory - which is based on empirical evidence that people do not behave in accordance with the normative models when it comes either to decision-making or choice.

Chen \& Tsao (2010) note four basic elements of the prospect theory:

- gains and losses are assessed relative to a particular reference point;

- despondency with regard to losses is higher than despondency towards gains (the disposition effect);

- a value function replaces the utility function of the expected utility theory; and

- decision weights replace the expected utility model's use of simple probabilities as a weighting function.

As indicated above, the value function in the prospect theory replaces the utility function of the expected utility theory. Value is not measured in terms of level of wealth, but in terms of gains and losses relative to a reference point.

Shiller (1999) clarifies the disposition effect when he states that, in fact, the prospect theory corresponds with the expected utility theory, in that people prefer to maximise a weighted sum of utilities. However, the concept of weighting in the two theories differs: weighting in the prospect theory is not the same as 
probabilities in the expected utility theory and in the prospect theory utilities are measured through the value function rather than through the utility function, as it would be measuredin the expected utility theory. A recent book by Daniel Kahneman (2011) argues that the expected utility theory makes logical assumptions, but that these do not reflect investors' actual choices; because the expected utility theory does not take into account the influence of behavioural biases in the decision-making process. Prospect theory constitutes the foundation on which the subject field of behavioural finance is based. An understanding of prospect theory facilitates the observation of human behaviour, and more importantly, the effects of human behaviour on financial decision-making and, ultimately, on the decision-making of property fund managers.

Frame dependence and property investment decision-making: Shefrin (2002) divides the field of behavioural finance into three main categories:

- heuristic-driven bias, which includes representativeness, overconfidence, anchoring-and-adjustment, conservatism, herding, aversion to ambiguity and emotion;

- frame dependence, which includes loss aversion and mental accounting; and

- market inefficiencies such as the mispricing of assets because of a lack of information.

The concept of frame dependence as a behavioural aspect implies that problems in respect of decisions may be modelled in different ways to that the decision frame of the decision-maker (Barberis \& Thaler 2003). A decision frame refers to the tendency to make present decisions within the framework in which the decision problem is presented. A decision frame relies on how a decision problem is posed, as well as on how it is perceived by the decision-maker. A decision frame also includes the personal characteristics of the decision-maker.

The effects of frame dependence on people's decisions as well as the influence of frame dependence on financial decision-making have been extensively investigated by Tverksy \& Kahneman (1981). One of their key findings was that people want to act in terms of their preferences and independently of the frame, but that uncertainty (difficulty) in resolving inconsistencies within that frame render them dependent on the frame. Shefrin (2002) indicates that the construct of frame dependence contradicts the expected utility theory, as well as the arguments put forward by the advocates of traditional finance, who assume that it is essential that people's decisions be consistent and/or transparent, regardless of the way in which the decision problem is presented. It emerges from the review of prospect theory that one of the key building blocks of prospect theory is the assumption that people's despondency regarding losses is higher than their despondency regarding gains. The disposition effect is based on this notion. The valuefunction, as explained above, also reveals that people are more pessimistic towards their losses in relation to their gains. Rabin (1998) confirms this notion when he claims that people prefer the status quo when changes to decisions may result in losses, in turn resulting in frame dependence. This aspect is also known as loss aversion. Godoi et al. (2005) conducted a qualitative study in which they investigated the factor of loss aversion in an investor environment. The results showed that the feeling of loss is socially constructed, and that it manifests in life experiences through familiarity, guilt, risks and losses, rationalisation, fear, anguish and, most significantly, loss aversion.

Fogel \& Berry (2006) conducted a study to investigate the disposition effect and individual investor decisions. They found that the majority of respondents display an a posteriori awareness of the long-term consequences of the disposition effect. Chen, Kim, Nofsinger \& Rui (2007) conducted a study of behavioural biases and emerging market investors, with special reference to Chinese investors. They established that the disposition effect is indeed present among these investors, who are not eager to incur losses, leading to an aversion of regret. In comparing their results with those of the US investor environment, these authors found that Chinese and US investors are both equally subject to the disposition effect. Benartzi \& Thaler (2007) examined loss aversion and found that myopic loss aversion occurs when portfolios are reviewed too often. In an earlier study, Brown and Lewis (1981) also investigated myopic behaviour by modulating topologies through the space of consumption plans of economic agents. The disposition effect and subsequent loss aversion can also be illustrated in the recent financial crisis. Szyszka (2010) explains that, because of the disposition effect, the market stagnated, with the emotion of fear preventing investors from entering the market. The market then experienced a further price drop, causing further fear and a state of risk aversion. In testing the invariance axiom of the expected utility theory among UK property professionals, the isolation effect - in terms of which rationality leads to consistency without framing dependence - was tested in a study conducted by Ye \& Dent (2009), who found that, as a result of isolation and inconsistent risk preferences, rationality amongst the group investigated was both questionable and in conflict with the expected utility theory. 
French \& French (1997) maintain that descriptive models should be implemented in order to help understand the way in which people make decisions, especially under uncertain conditions. Furthermore, they are of the opinion that the various decision-making models use different interpretations of risk, given the levels of uncertainty. They suggest that these differences may be best presented by applying mean variance analysis in terms of which the role of risk in decision-making is handled in isolation. Mean variance analysis would assist with the inconsistencies which arise from the application of the expected utility model, for example. People mentally create frames based on the decision problems posed to them. Frame dependence refers to decision frames, which depend on the way a decision problem is posed. These decision frames also depend on the way a decision problem is perceived by the decision-maker, by also taking into account the decision-maker's personal characteristics. The main problem, as discussed in this literature review, is that people want to make decisions independent of the decision frame that has been created. In other words, they want to make decisions in terms of their own preferences. However, the difficulty of resolving inconsistencies with the decision frame makes people dependent on that specific frame; thus, it makes them unable to see through or beyond the decision frame that has been created.

Loss aversion refers to a preference for maintaining the status quo when a change to a decision may result in losses, in other words, it refers to the fear of incurring a loss or regret. Loss aversion, as a result of frame dependence, in a property investment context, affects investment decision-making when adecisionmaker is afraid to invest in a property and consequently misses possible future gains. A loss-averse decision-maker tends to stay dependent on the initial decision frame. The person's fear is created by the risk of a possible future loss that may be incurredby investing in a property. The literature review revealed that the influence of frame dependence on property investment decision-making has not previously been investigated in a South African context. The literature clearly explains the presence and importance of this behavioural aspect and its influence on property investment decision-making in other countries. The current studytherefore adds to the existing knowledge in this discipline by investigating the impact and presence of frame dependence in the South African property context, which is especially relevant because South Africa is considered to be an emerging market, and such markets have been largely neglected in this type of research so far.

\section{Methodology}

In order to achieve the objectives and answer the research questions of this study, a survey-based design using survey-based data was adapted.The research instrument used in this study was a questionnaire.A preliminary questionnaire was designed to obtain sufficient information to draw usableconclusions in respect of the possible influence of frame dependence on property fund managers' investment decisionmaking. The effectiveness of the questionnaire in gathering the required information was pre-tested in a pilot study, which was also conducted to ensure that the test did not become too long. The questionnaire was designed to be as brief and as practical as possible to complete, in view of the amount of information needed. The questions asked and topic areas identified were based on the review of the related literature. The first section of the questionnaire requested participants to supply demographic information to be used in the final analysis. It included both open-ended and closed-ended questions on the respondent's gender, age, number of years of the property fund manager in the listed property fund industry, the number of years working at the current fund, highest academic qualification obtained, and any professional affiliations of the respondent.The demographic information was needed to measure the possible presence of behavioural aspects in the listed property fund managers' investment decisionmaking process, but individual responses were treated confidentially.

The second section of the questionnaire requested participants to provide vital fund information against which the possible presence of frame dependence in the listed property fund managers' investment decision-making process could bemeasured. The approximate size of the fund, the geographical market that the fund invests in, the percentage invested in the South African market, the property type invested in, the approximate number of properties in the fund, and the average return on 31 December 2011 were surveyed. The third section of the questionnaire referred to frame dependence, especially loss aversion (the fact that people do not want to lose) and the disposition effect (where participants hold on to losers and sell winners). This refers directly to the value function of the prospect theory and people's desire to avoid regret. The questions were based on work done by Fogel \& Berry (2006). The questionnaire was sent to the individual fund managers of all South African-based property funds listed on the Johannesburg 
Securities Exchange (JSE) on 31 December 2011. The questionnaire was sent out via email, and the fund managers were also contacteddirectly, asking them to participate in the study. Follow-up telephone calls were made to increase the response rate and produce a more rounded study. A total of 29 emails were sent to listed property fund managers, and 17 responses were received, constituting a response rate of $59 \%$. The 17 listed property fund managers who responded represented 16 of the 27 South African-based listed property funds. The total market capitalisation of the 27 South African-based listed property funds was R167.061 billion on 30 June 2012. The 16 listed property funds that participated in the survey contributed R133.672 billion (80\%) in market capitalisation to the South African listed property fund market in that period. It is acknowledged that one of the limitations of the study is that the sample size is relatively small, because of the limited number of listed property funds in South Africa.

\section{Results and Discussion}

In this section, in line with the main aim of this study, the results on the influence of frame dependence on the investment decisions made by listed property fund managers in South Africa areanalysed and discussed. Both the disposition effect (holding "losers" too long and selling "winners" too early) and loss aversion are analysed as aspects of frame dependence. The results contributed to the main research objective, which was to determine whether frame dependence influences the investment decisions of listed property fund managers in South Africa.

Descriptive statistics of the respondents: The respondents were predominantly male (94\%); there was only one female respondent. The average age of respondents was 45 years. They arewell educated, with $75 \%$ holding a post-graduate qualification. Of the participants, $71 \%$ are professionally affiliated in some way. They had, on average, spent nine years in the listed property fund industry in South Africa, and, on average, six years at the fund where they worked at the time of the study. The approximate fund size as indicated by the respondents is illustrated in Figure 1. The majority of the funds were larger than R1 billion, but smaller or equal to R5 billion. The three largest South African listed property funds, which all participated, have an approximate value of above R15 billion each. All the funds invest in South African properties, with two funds indicating that they also invest in other African countries. Only one fund specified investments in the rest of the world. The funds invest mainly in commercial, retail and industrial properties, with a small number of respondents indicating investments in residential, leisure and mixeduse properties. The average total return (capital and income growth) of the funds for 2011 was $8 \%$, with a minimum of $11 \%$ and a maximum of $16 \%$.

\section{Figure 1: Approximate fund size of South African listed property funds}

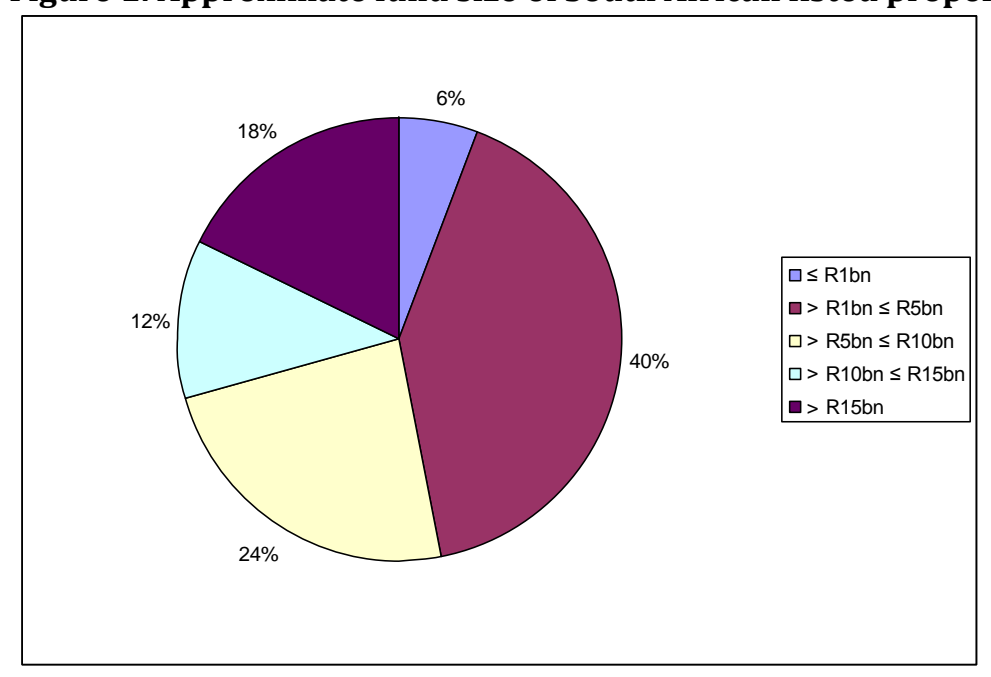

Regret about selling winners and holding on to losers: In this section, a set of questions was asked to gain insight into the possible influence of frame dependence in general, and the disposition effect and loss aversion in particular, on the decisions of listed property fund managers in South Africa. A question on feeling regret about selling a property too soon or holding onto a property for too long was put to the respondents. The results for this question are presented in Table 1. It is clear that all the respondents felt regret about not selling a "losing" property soon enough. No respondent showed any regret about selling a "winning" property too soon. 
Table 1: Regret about selling winners and holding on to losers

\begin{tabular}{lll}
\hline Thinking back to investment decisions that you now regret, & Frequency & Percentage \\
which one of the following do you feel more regret for: & & \\
\hline Selling a "winning" property too soon? & 0 & 0 \\
Not selling a "losing" property soon enough? & 17 & 100 \\
\hline
\end{tabular}

This finding is in agreement with Fogel \& Berry's (2006) study, which found that 59\% of their respondents showed regret at not selling a losing property soon enough. The listed property fund managers in South Africa thus clearly demonstrate a consciousness of the long-term side effects of the disposition effect. They tend to hold on to properties that do not add value to the fund for too long. The results in Table 1, above, therefore demonstrate the disposition effect, since the listed property fund managers' despondency about losses (not selling a "losing" property soon enough) is clearly higher than their despondency about gains (selling a "winning" property too soon). The influence of the disposition effect on the listed property fund managers in South Africa is that the fear of feeling regret may hinder their investing in properties that may realise positive financial gains in future.

Factors influencing selling decisions: Following the study of Fogel \& Berry (2006), the second question in this section was directly relevant to the question in Table 1 on regret about selling winning properties too soon or holding onto losing properties for too long.The respondents had to rate the importance of factors in decisions to sell a property. A Likert-type scale was used, ranging from 1 (not important at all) through 3 (standard importance) to 5 (most important). Table 2 shows the percentage of respondents who answered "most important" for each factor.

Table 2: The percentage of the "most important" rating of the factors in decisions to sell a property

\begin{tabular}{lll}
\hline \multicolumn{1}{c}{ Sell factor } & "Most important" rating & Percentage \\
\hline Desire to cut loss & 6 & 35.2 \\
End of fund/property life & 4 & 23.5 \\
Anticipated direction of the market & 3 & 17.6 \\
Need for liquidity & 2 & 11.7 \\
Desire to take profits & 1 & 5.8 \\
Desire to purchase an other property & 1 & 5.8 \\
The value of the property has reached its & 0 & 0 \\
predetermined target & & 0 \\
Outside the control of the fund manager & 0 & 0 \\
Broker recommendation & 0 & 0 \\
\hline (Note: Variable (1 to 5 Liker scale: 1=not important at all; 3=standard importance; 5=Most important); N=17)
\end{tabular}

The main factor that influences selling decisions by listed property fund managers in South Africa seems to be the desire to cut losses. The end of the fund/property life, followed by the anticipated direction of the market and the need for liquidity were the next most important factors to influence the participating fund managers' selling decisions. The less influential factors appeared to be the desire to realise profits and to purchase another property. The fact that the value of the property had reached its predetermined target, thatthe fund manager hadno control, and broker recommendations did not influence the respondents' selling decisions. The factors indicated by the respondents in the current study differ from those reported in Fogel \& Berry's (2006) study, where broker recommendations, an asset's reaching its predetermined target and the need for liquidity were citedas the main factors that influenced selling decisions. The current findings also contradict the observations made by Crosby \& McAllister (2004), Henneberry \& Roberts (2008) and MacCowan \& Orr (2008), who all found that property fund managers in the UK perceived restructuring at portfolio level as the most important decision factor that initiatesproperty disposal decisions in the UK. Underperformance was the next most important decision factor for property disposal decisions in the UK.

Fogel \& Berry (2006) suggest that the individual investors in their studydidnot act strictly normatively, as they indicateddependence on the recommendations of brokers in selling assets. The research by Crosby \& McAllister (2004), Henneberry \& Roberts (2008) and MacCowan \& Orr (2008), on the other hand, seems to be more in linewith the normative theory, becausethe disposal decision of property fund managers leads to a restructuring at the portfolio level, which is driven by forecasts on market fundamentals. It is interesting then that the South African listed property fund managersreporta desire to cut losses as the main driving factor to sell property. Their decisions would have been in line with normative behaviour if 
they kept winning properties, but they indicated that they had kept losing properties, because all regretted holding on to underperforming properties for too long. This confirms, in line with similar findings in the UK property market by Gallimore et al. (2000), that South African listed property fund managers may be loss averse.

The difficulty of, and time spent on, buying and selling property: The next two questions were designed totest the presence, or absence, of the disposition effect, as well as loss aversion. The first question was whether the listed property fund managers spend more time on buy or sell decisions regarding property investments. The second question asked which decisions (the buy or sell decisions) are more difficult to make. Tables 3 and 4show the results obtained in response to these questions respectively. These results may further substantiate the disposition effect, because, if it is more difficult to decide to sell a property, it may show that respondents display a greater despondency regarding losses. If more difficulty is associated with buying decisions, it may indicate a fear of investing in underperforming properties, suggesting loss aversion.If it is more difficult to make buy decisions than sell decisions, it may also indicate greater uncertainty in an opaque market. This means that the listed property fund managers may experience difficulties in confirming the market fundamentals of an unfamiliar asset to invest in, whereas the owner of a property has all the market fundamentals of the property available.

Table 3: Time spent on decisions to buy and sell a property

\begin{tabular}{lll}
\hline Buy and sell decision & Frequency & Percentage \\
\hline More time spent on decisions to buy a property & 15 & 88.2 \\
More time spent on decisions to sell a property & 0 & 0 \\
I spend about the same amount of time on each decision & 2 & 11.7 \\
\hline
\end{tabular}

The data in Table 3show that, without a doubt, the majority of respondents (88.2\%) spent more time on decisions to buy property. No respondents spent more time on selling property, and $11.7 \%$ of respondents spent about the same amount of time on both the buy and the sell decisions.

Table4: The difficulty of buy and sell decisionsrelating to property

\begin{tabular}{lll}
\hline Buy and sell decision & Frequency & Percentage \\
\hline Decisions to buy a property are more difficult & 12 & 70.5 \\
Decisions to sell a property are more difficult & 2 & 11.7 \\
The difficulty level is about the same & 3 & 17.6 \\
\hline
\end{tabular}

The data provided in Table 4shows that the majority of respondents (70.5\%) also find it difficult to make property buying decisions. Only $11.7 \%$ of respondents reported that they find it difficult to make property selling decisions, whereas $17.6 \%$ of respondents reported the difficulty level of choosing between buy and sell decisionsto be about the same. These findings support the findings of Fogel \& Berry (2006), indicating that the decision to buy is the most time-consuming, but the results contradicted the findings of Fogel \& Berry (2006), who found that selling decisions werethe most difficult to make. However, it should be remembered that this section of the study was adapted for the South African property market from the work of Fogel \& Berry (2006), who focused on individual investors in the US. Through the results above, it was established that the disposition effect influences the decision-making of listed property fund managers in South Africa, as the respondents all indicated feelings of regret atthe notion of holding onto losing properties rather than at that of selling winning properties. This finding also supportsthe results of previous research.The main reason for listed property fund managers in South Africa to dispose of property was a desire to cut losses. The anticipated direction of the market did not seem to be as important to them as the desire to purchase another property.Respondents also showed that it is more difficult and time-consuming to decide to buy properties than to sell them, implying that, together with the strong desire to cut losses, loss aversion is present.

\section{Conclusion and Recommendations}

The main objective of this study was to ascertain whether frame dependence as a behavioural aspect influences the investment decisions made by listed property fund managers in South Africa. The purpose of the study was to fill the gap that existed in such research in an emerging economy such as South Africa. In pursuit of the main objective of the study, specific sub-questions regarding the disposition effect, loss aversion, factors for making selling decisions, as well as the difficulties associated with, and time spent on buying and selling decisions were investigated. South African listed property fund managers may find it difficult to buy property because they have learned from past mistakes and now have a fear of investing 
in underperforming properties.This result corroborates research findings reported by Tversky \& Kahneman (1981), Rabin (1998), Shefrin (2002) and Godoi et al. (2005) on the presence and influence of the disposition effect, loss aversion, and feelings of regret in respect of investors' selling "winners" and holding onto "losers" as investments.The emotion of fear was also noted by Szyszka (2010) in a study on the behavioural anatomy of the financial crisis. He argues that this fear was caused by the recent financial crisis, resulting in the subsequent appearance of the disposition effect and loss aversion. Chen et al. (2007) also found evidence of the presence of the disposition effect and subsequent loss aversion in emerging markets, referring specifically to Chinese investors.

The current study on the influence of frame dependence on the investment decisions made by listed property fund managers in South Africa found that the disposition effect is present. There was a clear indication that respondents all feel more regret towards holding a losing property too long than selling a winning property too soon.Furthermore, the respondents indicated that the desire to cut losses was their most important reason for selling property. Together with the difficulties they pointed out in making buying decisions and the associated feelings of regret aboutholding on to losing properties,it can be argued that frame dependence, the disposition effect and loss aversion do influence the South African listed property sector. The major outcome of this study was that frame dependence, as a behavioural aspect, does influence the investment decisions made by listed property fund managers in South Africa. The disposition effect was evident. The listed property fund managers had a strong desire to cut losses and reported that they find it difficult to make buying decisions, which is indicative of loss aversion.

Based on this study's findings, it is clear that the subject area of behavioural finance, with special reference to real estate, does have a practical application. Frame dependence in particular is prominent in property investors' investment decision-making. It is therefore recommended inthis study that fund managers be made aware of these aspects so that they can incorporate this awareness in their normative investment strategies in order to achieve maximum wealth.South African listed property fund managers need torecognise that they are loss averse in their investment decision-making. Their strongdesire to cut their losses and the associated difficulties in making buying decisions means that they tend to be conservative. This behaviour may be associated with the global financial crisis, but if they are overly loss averse, fund managers may missperfectly positioned, profitable investment opportunities. It is recommended through this study that further research be undertaken in comparing this study with data on property fund managers in other emerging countries to establish possible similarities or differences. An investigation on the investment strategies of listed property funds may further clarify the presence of the disposition effect and subsequent loss aversion. Although this study was limited by the small sample surveyed, it doesenhance understanding of the role that is played by frame dependence, specifically the disposition effect and loss aversion, in the South African property industry. More importantly, it goessome way towards enhancing understanding of frame dependence and its influence on property investment decision-making in South Africa.

\section{References}

Barberis, N. \& Thaler, R. (2003). A survey of behavioural finance. In: Constantinides, M.H. \&Stulz, R. (eds.), Handbook of Economics and Finance (pp. 1054-1123). Amsterdam: Elsevier.

Benartzi, S. \& Thaler, R. H. (2007). Heuristics and biases in retirement savings behavior. Journal of Economic Perspectives, 21(3), 81-104.

Black, R. T., Brown, G. M., Diaz III, J., Gibler, K. M. \& Grissom, T. V. (2003). Behavioral research in real estate: a search for the boundaries. Journal of Real Estate Practice and Education, 15(3), 85-112.

Brown, D. \& Lewis, L. M. (1981). Myopic economic agents. Econometrica, 49(2), 359-368.

Chen, G., Kim, K. A., Nofsinger, J. R. \& Rui, O. M. (2007). Trading performance, disposition effect, overconfidence, representativeness bias, and experience of emerging market investors. Journal of Behavioral Decision Making, 20, 425-451.

Chen, W. K. \& Tsao, C. T. (2010). The third order cumulative prospect stochastic dominance in portfolio management. Working paper. Kaohsiung, Taiwan:

Crosby, N. \& McAllister, P. (2004). Deconstructing the transaction process, Working Paper 2.In: Bond,S., Crosby, N., Hwang, S., Lizieri, C., Matysiak, G., McAllister, P.\& Ward, C. (eds.), Liquidity in Commercial Property Markets: Research Findings(pp. 22-39). London: IPF.

Doeswijk, R. Q. (1997). Contrarian investment in the Dutch stock market. De Economist, 145(4), 573-598.

Fama, E. F. (1970). Efficient capital markets: a review of theory and empirical work. Journal of Finance, 25(2), 383-417. 
Fogel, S. O. C. \& Berry, T. (2006). The disposition effect and individual investor decisions: the roles of regret and counterfactual alternatives. Journal of Behavioral Finance, 7(2), 107-116.

Frederick, S., Loewenstein, G. \& O'Donoghue, T. (2002). Time discount and time preference: a critical review. Journal of Economic Literature, 40, 351-401.

French, N. \& French, S. (1997). Decision theory and real estate investment. Journal of Property Valuation \& Investment, 15(3), 226-232.

Gallimore, P., Hansz, A. J. \& Gray, A. (2000).Decision making in small property companies.Journal of Property Investment \& Finance, 18(6), 602-612.

Godoi, C. K., Marcon, R. \& Da Silva, B. (2005). Loss aversion: a qualitative study in behavioural finance. Managerial Finance, 31(4), 46-56.

Henneberry, J. \& Roberts, C. (2008). Calculated inequality? Portfolio benchmarking and regional office property investment in the UK. Urban Studies, 45(5\&6), 1217-1241.

Hennings, K. \& Samuels, W. (1990). Neoclassical Economic Theory, 1870 to 1930. Norwell, MA: Kluwer Academic.

Kahneman, D. (2011). Thinking, Fast and Slow. New York, NY: Farar, Straus and Giroux.

Kahneman, D. \& Tversky, A. (1979). Prospect theory: an analysis of decision under risk. Econometrica, $47(2), 263-291$.

Keynes, J. M. (1936). The General Theory of Employment, Interest and Money. London: Palgrave Macmillan.

MacCowan, J. R. \& Orr, A. M. (2008). A behavioural study of the decision processes underpinning disposals by property fund managers. Journal of Property Investment \& Finance, 26(4), 342-361.

Markowitz, H. M. (1959). Portfolio Selection: Efficient Diversification of Investments. London: YaleUniversity Press.

Menkhoff, L. \& Nikiforow, M. (2009). Professionals' endorsement of behavioural finance: does it impact their perception of markets and themselves? Journal of Economic Behavior\& Organization, 71, 318-329.

Mooya, M. (2010). The South African property industry: overview and issues for research. Acta Structilia, 17(2), 149-169.

Muneer, S. \& Rehman, S. U. (2012). Materialization of Behavioral Finance and Behavioral Portfolio Theory: A Brief Review. Journal of Economics and Behavioral Studies, 4(8), 431-435

Rabin, M. (1998). Psychology and economics. Journal of Economics Literature, 36, 11-46.

Ramabodu, M. S., Kotze, B. G. \& Verster, J. J. P. (2007). Diversity and value in Africa's real estate. Journal of Property Investment \& Finance, 25(1), 7-22.

Samuelson, P. (1937). A note on measurement of utility. Review of Economic Studies, 4, 155-161.

SAPOA/IPD South Africa Annual Property Index. (2011). Results for the year to December 2011. Morningside, South Africa: Investment Property Databank.

Sargent, T. J. (2010). Rational expectations [Homepage of Library of Economics and Liberty], [Online]. Available: http://www.econlib.org/library/Enc/ RationalExpectations.html [Accessed 2010-0914].

Savage, L. J. (1954). The Foundations of Statistics. New York, NY: Wiley.

Schoemaker, P. J. H. (1980). Experiments on Decisions under Risk: the Expected Utility Hypothesis. Boston, MA: Nijhoff.

Shefrin, H. (2002). Beyond Greed and Fear: Understanding Behavioural Finance and the Psychology of Investing. New York, NY: OxfordUniversity Press.

Shiller, R. J. (1999). Human behavior and the efficiency of the financial system. In: Taylor, J.B. \& Woodford, M. (eds.), Handbook of Macroeconomics (pp. 1306-1334). New Haven, CT: Elsevier Science.

Shiller, R. J. (2003). From Efficient Markets Theory to behavioural finance. Journal of Economic Perspectives, 17(1), 83-104.

Stracca, L. (2004). Behavioral finance and asset prices: where do we stand? Journal of Economic Psychology, 25, 373-405.

Szyszka, A. (2010). Behavioral anatomy of the financial crisis. Journal of CENTRUM Cathedra, 121-135.

Tversky, A. (1975). A critique of expected utility theory: descriptive and normative considerations. Erkenntnis, 9(2), 163-173.

Tversky, A. \& Kahneman, D. (1981). The framing of decisions and the psychology of choice.Science, 211(4481), 453-458.

Von Neumann, J. \& Morgenstern, O. (1947).Theory of Games and Economic Behavior, Princeton, NJ: Princeton University Press.

Ye, X. \& Dent, P. (2009). Invariance assumptions among the UK property professionals' decision-making. Journal of European Real Estate Research, 2(1), 56-68. 